\title{
Colonialism and Postcolonialism
}

Daniel Butt, University of Bristol

Forthcoming in Hugh LaFollette (ed.), The International Encyclopedia of Ethics (Wiley-Blackwell, 2013)

Much of the history of international relations is characterized by the violent attempts of one community to subjugate another. In 1955, Aimé Césaire wrote of the "great historical tragedy" that befell Africa in its encounter with European colonialism, an encounter that led Césaire to conclude that "Europe is responsible before the human community for the highest heap of corpses in human history" (2000: 45). A range of important ethical issues emerges from a consideration of the past interaction between colonizing and colonized peoples, both in the African context and elsewhere in the world. This article first seeks to describe the key characteristics of colonialism as a system of domination and subjugation, before considering the legitimacy of contemporary judgments on the morality of historical colonialism. It then examines how the particular character of colonialism complicates arguments relating to the rectification of injustice. It concludes by asking what lessons those interested in ethics can learn from the diverse body of work produced by writers in the postcolonial tradition.

\section{Defining Colonialism}

Defining colonialism is not a straightforward task. A variety of forms of historic and contemporary interaction between different peoples have been described as colonial or neo-colonial in character, and this poses problems: define the term too narrowly, and particular communities who have experienced injustice which they characterize as colonial are excluded; too broadly, and almost any form of relation featuring inequality of power between different international parties appears to be an instance of colonialism. Robert Young writes that colonialism "involved an extraordinary range of different forms and practices carried out with respect to radically different cultures, over many centuries," and lists examples including settler colonies such as British North America and Australia, and French Algeria; administered territories established without significant settlement for the purposes of economic exploitation, such as British India and Japanese Taiwan; and maritime enclaves, such as Hong Kong, Malta, and Singapore (2001: 17). A recurrent problem concerns the relation between the terms "colonialism" and "imperialism." For some, "colonialism" refers to a particular model of political organization, typified by settler and exploitation colonies, and is best seen as one specific instance of imperialism, understood as the domination of a territory by a separate metropole. Others 
use the term more broadly to refer to the general imperial policy of, in particular, Western states from the sixteenth century onward, reflecting an oppressive attitude which, some claim, still persists in the present day, albeit in different institutional forms. Attempts to establish general theories of colonialism thus encounter problems similar to those found in systematizing liberation ideologies such as feminism, which are rooted in the "experiential plurality" of those who have experienced different forms of oppression (Mansbridge and Okin 1993: 269; see FEMINIST ETHICS; FEMINIST POLITICAL THEORY). The range of different forms of political organization which are routinely described as "colonial" means that overly stipulative definitions should be resisted. Instead, we might identify three characteristics which regularly emerge in descriptions of colonialism: domination, cultural imposition, and exploitation. First, colonialism is typically described as a form of domination which involves the subjugation of one people by another; as Ronald Horvath writes, "it seems generally, if not universally, agreed that colonialism is a form of domination - the control by individuals or groups over the territory and/or behavior of other individuals or groups" (1972: 47). This domination has taken varied institutional forms, but in general has involved the denial of selfdetermination, and the imposition of rule rooted in a separate political jurisdiction. Second, colonialism has frequently involved an attempt to impose the colonial power's culture and customs onto the colonized, whether as a result of a belief in the racial and/or cultural superiority of the colonizing power; an evangelical desire to spread particular religions or cultural practices; or as a mechanism for establishing and consolidating political control. Finally, the history of colonialism is deeply linked to the exploitation of colonized peoples (see EXPLOITATION). This exploitation has taken many different forms, but we might mention, among other policies, the slave trade, the misappropriation of cultural property and natural resources, the establishment of exploitative trade relations, and the forcible introduction of capitalist forms of production. As will be seen, the legacy of such practices is deeply contested.

\section{Justifying and Judging Colonialism}

The question of how, and indeed whether, we should judge historical colonialism from an ethical perspective is complex. For some, the practice of passing judgment on the past is problematic, since it seems to involve holding historic actors to account on the basis of contemporary standards of morality. It is clear that, at various points in time, historical acceptance of the propriety of much colonial practice was widespread. Strikingly, the legitimacy of colonial intervention was supported by prominent political theorists who otherwise placed great emphasis on principles of liberty and equality, such as John Locke (see LOCKE, JOHN) and John Stuart Mill (see MILL, JOHN STUART; Parekh 1995). Does it follow that we cannot assess historic colonialism in moral terms, even though 
we would readily condemn such actions if they were performed in the present day? It is helpful here to differentiate between two separate questions. One concerns judgment of the moral character of the colonialists - were they good or bad people? The second concerns the justice or injustice of the practice of colonialism: were the individuals affected by colonialism wronged by the treatment they received? Both questions are of interest, but the first can be separated from an ethical judgment as to the justice of the practices and institutions of colonialism. The claim that historic colonialism involved at least some serious injustice is now uncontroversial. It is true that some have sought to put forward accounts based in moral relativism (see RELATIVISM, MORAL) to counsel against retrospective judgment: just as cultural relativists maintain that questions of justice should be understood relative to the shared social meanings of particular societies, so historical relativists can argue that similar considerations apply to the different standards of the past. One could maintain that historic colonialism was just simply because historic persons believed it to be just, but this would obviously be deeply controversial when one considers the character of colonial history. At some times and in some places, colonial domination involved multiple instances of genocide, slavery, rape and sexual enslavement, murder, torture, and the forcible displacement of people and break-up of families. Some peoples, indeed, no longer exist as a direct result of colonialism, as in the case of the Parlevar people of Tasmania. The claim that such actions were deeply unjust can be made from a variety of ethical perspectives. The argument is relatively straightforward if one endorses an idea of universalism, which holds that such actions are straightforwardly wrong on account of the way in which they cause profound harm to people's most basic interests. Alternatively, moral relativists can maintain that such actions were wrong even by the different standards of the day, properly understood: either as a result of the factually incorrect premises that grounded many colonial theories (in relation, e.g., to the supposed racial superiority of the colonial powers); or owing to the way that historical principles of equality and liberty were comprehensively violated by colonial policies. Historic colonialism was not universally supported within colonial powers, as can be seen in the reservations expressed by writers such as Bartolomé de Las Calas, Denis Diderot (see DIDEROT, DENIS), and Adam Smith (see SMITH, ADAM; Young 2001: 71-112). The basic claim that historic colonialism involved, at the least, significant injustice can thus be advanced from a range of ethical positions.

Colonialism and Rectification

It is much disputed whether anything follows from an acceptance of the unjust character of colonialism, as is clear from contemporary debates over the payment of reparations (see REPARATIONS) by the modern-day counterparts of historic colonial powers. Such states have made moves toward acknowledging the injustice of historic colonialism, so, for example, The Declaration 
on the Granting of Independence to Colonial Countries and Peoples, adopted by the UN General Assembly in 1960, accepted that "the subjection of peoples to alien subjugation, domination and exploitation constitutes a denial of fundamental human rights" (article 1). The 2001 United Nations World Conference against Racism, Racial Discrimination, Xenophobia, and Related Intolerance in Durban acknowledged and regretted the "massive human suffering" caused by slavery and colonialism (article 99), but was also marked by the refusal of former colonial powers to commit to making formal apologies or paying reparations. States may seek to resist such demands for material recompense for obvious reasons of national self-interest. The relative weakness of international law, and, in particular, its lack of retrospective effect, means that such states cannot plausibly be compelled to pay reparations, and former colonial powers have regularly invoked statutes of limitations to avoid the claims even of living victims of acknowledged injustice, as in the controversy over whether the UK Government should pay compensation to individuals tortured during the Mau Mau insurgency in Kenya in the 1950s. Leaving legal issues aside, is it justifiable for modern-day states to refuse to put right the misdeeds of their colonial forbears?

Positive responses typically fall into one of two camps. Some stress the shared identity of people living in the past and the present, through membership of collectivities such as nations and states. Others are grounded in the lasting effects of past wrongdoing, and maintain that modern-day parties can possess contemporary duties insofar as they have benefited from, and others have been harmed by, the lasting effects of colonization (Butt 2007; see COMPENSATORY JUSTICE). The particular character of historic colonialism complicates standard arguments relating to the rectification of injustice in a number of ways. Some relate to the discontinuities of nation and state identity which often result from colonial domination. Debates over historic injustice notoriously face the "nonidentity problem": the observation that significant past wrongdoing changes the composition of subsequent generations by making a difference to which particular individuals are conceived and come into existence (see NONIDENTITY PROBLEM). This has particular force in colonial contexts characterized by massive displacement of persons and the deliberate redrawing of political boundaries, where it is not even clear if particular modern-day states would exist in the absence of historic injustice, let alone particular individuals. Such observations have two implications for consideration of colonial injustice. First, there are significant issues as to inherited identity - to what extent is it meaningful to say that a given state is the present-day representative of a historic, wronged people, or of an unjust colonial power? Second, given the enormity of the disruption of the lives of historic communities caused by colonial activity, to what extent can we meaningfully employ ideas of counterfactual reasoning to determine the extent, if any, to which present-day peoples have benefited or been harmed by activities associated with colonization? 
A particular problem here concerns the prior identification of colonialism as characteristically exploitative. Some historians have challenged the claim that the current members of particular historically mistreated peoples have themselves been harmed by colonial injustice, as a result of a deeply controversial argument that such persons may in fact have gained a net benefit from the treatment of their ancestors (Ferguson 2002). This claim must be assessed carefully. It does not in itself represent a defense of historic colonialism: it might still be maintained that colonialism has not led to an overall net benefit for the colonized people when the suffering of past persons is taken into account, or that even a net overall benefit would be insufficient to justify colonialism on anything but the crudest consequentialist accounts. However, the question of the status of current generations is seemingly relevant to the question of contemporary reparations, if their rationale is grounded in the idea that past injustice has caused harm to those living in the present. We might consider three possible responses to such an argument. First, the empirical assumption of the argument might be challenged: many historians have disputed upbeat assessments of the contemporary effects of colonialism, and have instead pointed to a lasting legacy of failed states and intercommunity violence (Brendon 2007). Second, one may question how counterfactual comparisons to identify harm and benefit should be made in relation to colonial exploitation. This is generally done by reference to assumptions of the most probable outcome in the absence of colonial intervention: we are asked to imagine a world where there was no interaction between colonized and colonizers, and thus no colonial injustice, and to determine whether those living in the present are now better or worse off than they would be in comparison. However, this is not the only, and arguably not the most appropriate, way to calculate who has won and who has lost. It may better to imagine a counterfactual where there was extensive interaction, fully consensual in nature, that took place in a context of nondomination and nonexploitation, and which would seemingly require very substantial levels of compensation in some cases (Butt 2012). Third, one may expand one's understanding of the wrongs committed in the colonial period to encompass failures to fulfill duties of distributive justice. Insofar as historic colonial empires subjected peoples to political control, it may be thought that colonial subjects became members of a larger political entity, and so were entitled to a fair share of this entity's social production - a share which was denied to them at the point of institutional decoupling during decolonization. If one holds, for example, an egalitarian account of distributive justice, and believes that there has been an ongoing failure to transfer what is owed, then present-day reparative obligations may be colossal (Ypi et al. 2009).

Postcolonialism and Ethics 
It has been argued that, despite its institutional variation, colonialism typically displays three characteristics: domination, exploitation, and cultural imposition. Much work on colonialism within contemporary political theory and ethics has focused on the extent to which its exploitative character has had lasting effects on present-day distributions of benefits and burdens. A different perspective is taken by writers working within the postcolonial tradition, which, taking its lead from literary studies, emphasizes a variety of topics relating to the cultural effects of colonization. Postcolonialism does not simply seek to tell the story of what happened after decolonization, but seeks a critical perspective on its ongoing, problematic legacy: as Young writes, "Postcolonial critique focuses on forces of oppression and coercive domination that operate in the contemporary world: the politics of anticolonialism and neo-colonialism, race, gender, nationalism, class and ethnicities define its terrain" (2001: 11). A key theme here is that there is more to achieving liberation through decolonization than the formal decoupling of state apparatuses: as Diana Brydon writes, "Postcolonialism matters because decolonization is far from complete and colonial mentalities, including the inequalities they nurture, die hard" (Kohn and McBride 2011: 8). A sense of the diversity of work in this field can be gained from Stephen Slemon's description of some its associated perspectives:

It has been used as a way of ordering a critique of totalizing forms of Western historicism; as a portmanteau term for a retooled notion of "class," as a subset of both postmodernism and poststructuralism; as the name for a condition of nativist longing in post-independence national groupings; as a cultural marker of nonresidency for a Third World intellectual cadre; as the inevitable underside of a fractured and ambivalent discourse of colonialist power; as an oppositional form of "reading practice"; and ... as the name for a category of "literary" activity which sprang from a new and welcome political energy going on within what used to be called "Commonwealth" literary studies (quoted in Ashcroft et al. 2007: 169-70).

Giving a general characterization of such varied approaches is not easy. Indeed, much postcolonial writing seeks to challenge the way in which the history of colonization and decolonization has been related and categorized by European writers, rather than by members of nonEuropean and non-Western communities who themselves experienced the injustice of colonization. From the perspective of writers such as Edward Said, the production and control of knowledge itself constitutes an exercise of power (Said 1978), meaning that an analysis of the domination characteristic of colonialism must seek to take account of the cultural meanings which attach themselves to our attempts to understand both past and present. What this suggests is that a literature on the ethics of colonialism written by Western academics with little regard to the voices of those who have suffered domination runs the risk not only of misunderstanding the nature, but of compounding the effects, of historical injustice. The ethical implications of this for those working within Western traditions are twofold. First, engagement with non-Western writing can help to improve understanding 
of the rights and wrongs of colonialism, and also of the broader questions of global justice and multicultural citizenship: by deepening our understanding of the cultural lives of others, but also by challenging our own moral principles and assumptions, particularly in relation to the primacy of liberal democracy and moral universalism (see AFRICAN ETHICS). Kohn and McBride, for example, have recently drawn extensively on the work of a wide range of postcolonial writers, such as Ngugi wa Thiong'o, Jalal al-e Ahmad, Amílcar Cabral, and José Mariátegui, largely neglected in Western political thought, to reflect on the nature of political change and the foundation of new regimes, with a stated aim of challenging colonial power and perceptions by setting up a clash between liberal democratic and postcolonial ideological positions (Kohn and McBride 2011: 13). Second, it may be that such an engagement is not only helpful for thinking about colonial wrongdoing, but forms a constitutive part of a proper rectificatory response. If one understands the wrongs of colonialism not just in terms of economic exploitation and physical violence, but also in relation to the establishment of ongoing forms of cultural imposition and domination, then there are powerful reasons for seeking to include non-Western voices in academic writing on colonization and decolonization.

SEE ALSO: AFRICAN ETHICS; COMPENSATORY JUSTICE; DIDEROT, DENIS; EXPLOITATION; FEMINIST ETHICS; FEMINIST POLITICAL THEORY; LOCKE, JOHN; MILL, JOHN STUART; NONIDENTITY PROBLEM; RELATIVISM, MORAL; REPARATIONS; SMITH, ADAM.

\section{References}

Ashcroft, Bill, Gareth Griffiths, and Helen Tiffin 2007. Post-Colonial Studies: The Key Concepts. Abingdon: Routledge.

Brendon, Piers 2007. “A Moral Audit of the British Empire,” History Today, vol. 57, pp. 44-7.

Butt, Daniel 2007. “On Benefiting from Injustice,” Canadian Journal of Philosophy, vol. 37, pp. 12952.

Butt, Daniel 2012. "Repairing Historical Wrongs and the End of Empire," Social and Legal Studies, vol. 21, pp. 227-242.

Césaire, Aimé 2000. Discourse on Colonialism. New York: Monthly Review Press. 
Ferguson, Niall 2002. Empire: The Rise and Demise of the British World Order and the Lessons for Global Power. London: Allen Lane.

Horvath, Ronald J. 1972. “A Definition of Colonialism,” Current Anthropology, vol. 13, pp. 45-57.

Kohn, Margaret, and Keally McBride 2011. Political Theories of Decolonization: Postcolonialism and the Problem of Foundations. Oxford: Oxford University Press.

Mansbridge, Jane, and Susan Moller Okin 1993. "Feminism," in R. Goodin and P. Pettit (eds.), A Companion to Modern Political Philosophy. Oxford: Blackwell, pp. 269-90.

Parekh, Bhikhu 1995. "Liberalism and Colonialism: A Critique of Locke and Mill," in Jan Nederveen Pieterse and Bhikhu Parekh (eds.), The Decolonization of Imagination: Culture, Knowledge and Power. London: Zed, pp. 81-98.

Said, Edward 1978. Orientalism: Western Conceptions of the Orient. New York: Pantheon.

Young, Robert 2001. Postcolonialism: An Historical Introduction. Blackwell: Oxford.

Ypi, L., R. Goodin, and C. Barry 2009. "Associative Duties, Global Justice, and the Colonies," Philosophy and Public Affairs, vol. 37, pp. 103-35.

Suggested Readings

Barkan, Elazar 2000. The Guilt of Nations: Restitution and Negotiating Historic Injustices. New York: Norton.

Butt, Daniel 2009. Rectifying International Injustice: Principles of Compensation and Restitution Between Nations. Oxford: Oxford University Press.

Ferro, Mark 1997. Colonization: A Global History. London: Routledge.

Hiddleston, Jane 2009. Understanding Postcolonialism. Stocksfield: Acumen.

Kohn, Margaret 2010. "Post-Colonial Theory," in Duncan Bell (ed.), Ethics and World Politics. Oxford: Oxford University Press, pp. 200-18.

Larsen, Neil 2000. “Imperialism, Colonialism, Postcolonialism," in Henry Schwarz and Sangeeta Ray (eds.), A Companion to Postcolonial Studies. Oxford: Blackwell, pp. 23-52. 
Lu, Catherine 2011 "Colonialism as Structural Injustice: Historical Responsibility and Contemporary Redress," Journal of Political Philosophy, vol. 19, pp. 261-81.

Miller, David 2007. National Responsibility and Global Justice. Oxford: Oxford University Press.

Tan, Kok-Chor 2007. "Colonialism, Reparations, and Global Justice," in Jon Miller and Rahul Kumar (eds.), Reparations: Interdisciplinary Inquiries. Oxford: Oxford University Press, pp. 280306.

Venn, Couze 2007. The Postcolonial Challenge: Towards Alternative Worlds. London: Sage.

Young, Robert 2003. Postcolonialism: A Very Short Introduction. Oxford: Oxford University Press. 